\title{
Penile Reconstruction after Polymethilmetacrylate Injection
}

\author{
Haddad-Tame José Luis, ${ }^{*}$ Rincon-Lozano Rogelio, Morel-Fuentes Elsa Jacqueline Juliette, Priego-Blancas Raymundo \\ Plastic Aesthetic and Reconstructive Surgeon, Mexico
}

\begin{abstract}
Rising number of aesthetic procedures in men directed to enhance genitalia has alerted the medical community due to several complications related to them. Most of those procedures are performed in an office under local anesthesia using different kind of substances, most of them known to be harmful for humans; still, patients seek those procedures as a "safe" way to meet their goals. We present a reconstruction case due to Polymethilmetacrylate injection for penile enhancement.
\end{abstract}

Keywords: Penile, Reconstruction, Polymethilmetacrylate

\section{Case Report}

It isn't new nor a recent practice of several so called "easy", "in and out office" enhancing procedures. History of adjuvant substances such as petroleum jelly (liquid Vaseline) date back 1886 reported by Balzer ${ }^{1}$ used to correct a scrotal deformity caused by tuberculosis infection, he described the complications caused by its use. Polymethylmethacrylate (PMM) has been widely accepted in orthopedic surgery since Judet ${ }^{2}$ introduced the first hip prosthesis made from PMM. As PMM in orthopedic surgery is considered highly biocompatible, in 1996 McClelland et al., ${ }^{3}$ evaluated its use as Soft-Tissue augmentation, in their animal study, they found that PMM implant did not appear to be a useful alternative for soft-tissue augmentation; they described that Artecoll (a brand of PMM) is difficult to extrude, even though through a large 27-gauge needle, moreover, all implant sites showed an increasing inflammatory reaction over time.

Grassi et al., ${ }^{4}$ reported complications of PMM use as aesthetic soft-tissue filler in 32 patients, although PMM is widely used in Brazil for face and body enhancement, most of the patients showed complications 6 to 12 months after the procedure and even years later, implant site might get a chronic inflammatory reaction. The appearance of symptoms may differ according to the site of injection, type of the substance, quantity and patient inherent immune response. ${ }^{5}$ Treatment can become challenging due to material migration and increasing risk of an autoimmune response that may continue even after removing the forieng material. ${ }^{6-8}$ The majority of cases will show skin compromise even after removing the substance, for that reason, some patients can get a greater benefit if treatment is directed not only to remove the underlying substance but replacing the skin by using different cutaneous flaps or skin grafts. $^{7,9}$

There is an increasing industry that claims a risk free penile enhancement that lacks scientific support. Despite the increasing number of complications reported in medical literature, physicians and non medical practitioners still use PMM for penile augmentation. A 32 year old man was referred to my office due to PMM injection of twelve syringes for penile augmentation; the original procedure was performed by an Urologist at his office three years before his consultation, 2 years later the patient noticed an increasing penile deformity due to severe fibrosis accompanied with erectile problems and an increasing urination difficulty, the patient was treated by a plastic surgeon that managed the complication by re-

\begin{tabular}{|l|l|}
\hline Quick Response Code: & *Corresponding author: Haddad-Tame José Luis, Miguel de Cervantes Saavedra 233. 4to piso, \\
Col. Granada. 11520 CD, Mexico \\
Received: 03 March, 2021 \\
Citation: Haddad TJL, Rincon LR, Morel FEJJ, Priego BR. Penile Reconstruction after Poly- \\
methilmetacrylate Injection. Mod Res Plast Recon Sur. 2021;1(1):1-3. DOI: 10.53902/MR- \\
PRS.2021.01.000505
\end{tabular}


moving all the affected tissue including the skin. To give temporal coverage, he covered the entire phallus with scrotal skin, leaving exposed the unaffected glands.

Physical examination revealed the glans sutured to the scrotum (Figure 1) with complete coverage of the phallus, there were no palpable lymph nodes in the groin. To provide an aesthetic and sensitive coverage; we designed a free radial flap (Figure 2); at first we released the phallus from its temporal scrotal coverage (Figures 3\&4); once we assessed the actual penile length, we dissected the recipient right deep inferior epigastric vessels and apudendal nerve branch (Scheme 1-3); once we had one artery, two veins and the sensitive nerve, we released the flap from the right forearm and made the proper neurovascular micro anastomosis under magnification; then we covered the entire perimeter of phallus with the radial flap and reconstructed the donor site with a full thickness skin graft. In the follow up, the patient asked for flap defatting, which we performed safely through microcannula liposuction. Patient resumed normal sexual life without any issue.

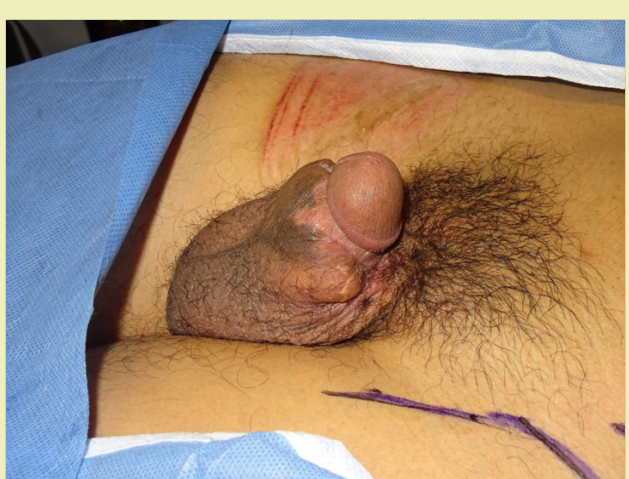

Figure 1: Patient outcome after PMM removal with penile foreskin and phallus coverage with scrotal skin.

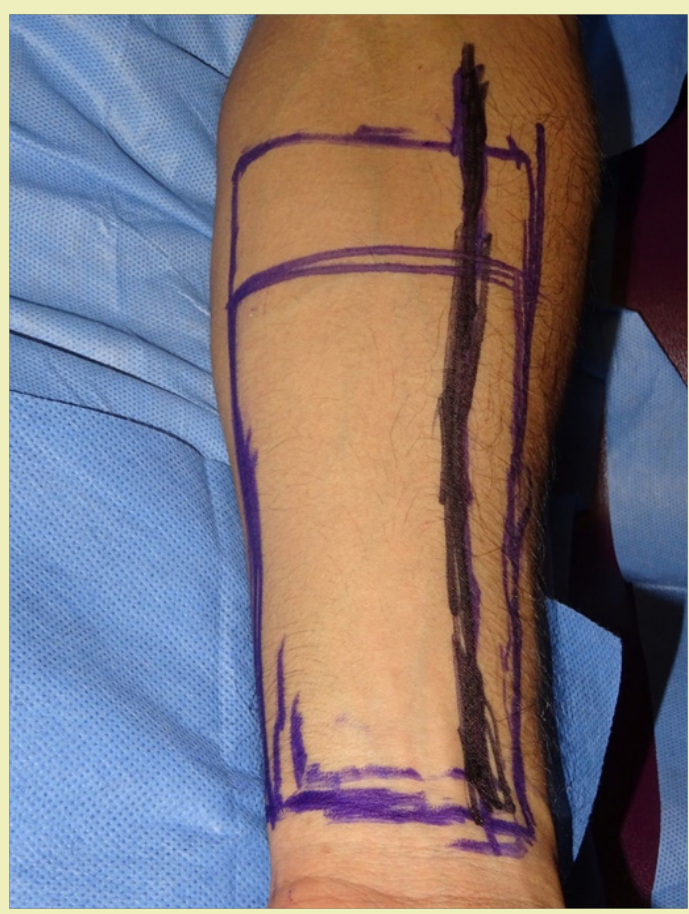

Figure 2: Fasciocutaneus Radial flap planning.

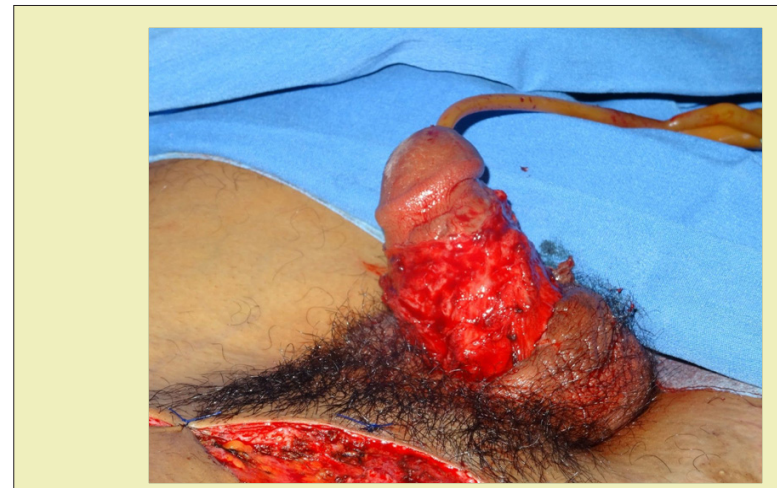

Figure 3: Phallus appearance after releasing it from its scrotal skin coverage.

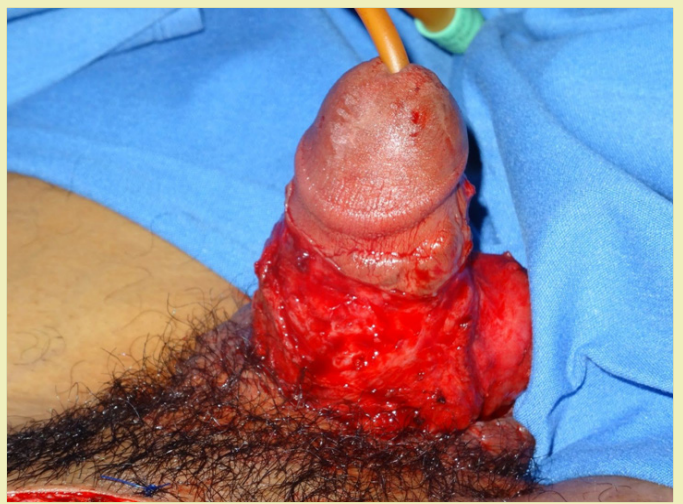

Figure 4: Phallus appearance after releasing it from its scrotal skin coverage closer view.

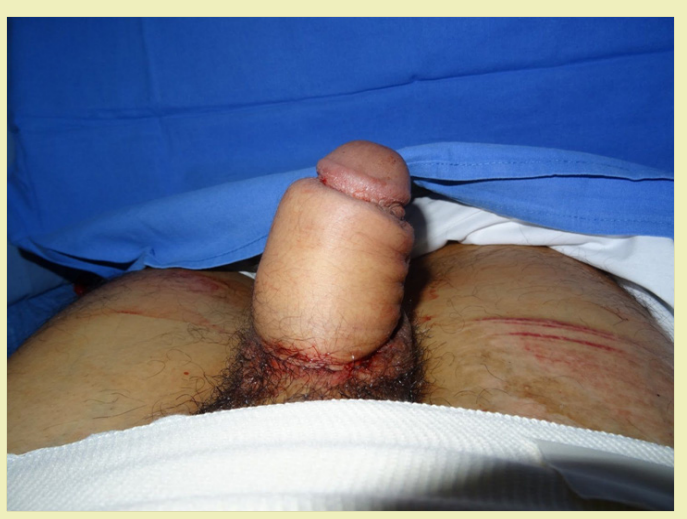

Figure 5: Immediate PO after penile reconstruction covering the phallus with a fasciocutaneus radial flap.

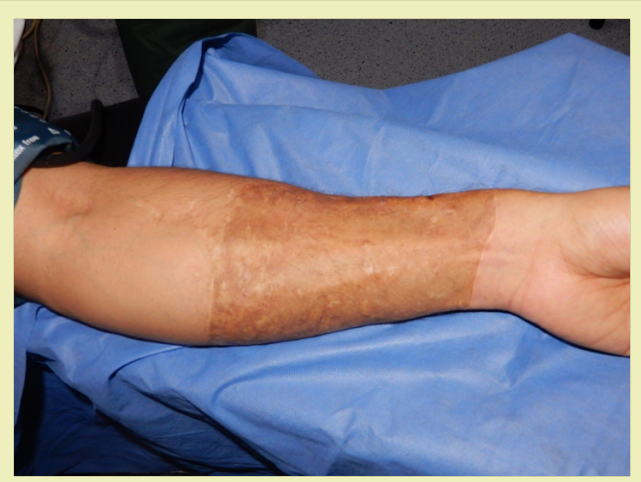

Figure 6: Donor site reconstructed with sking graft with full integration 


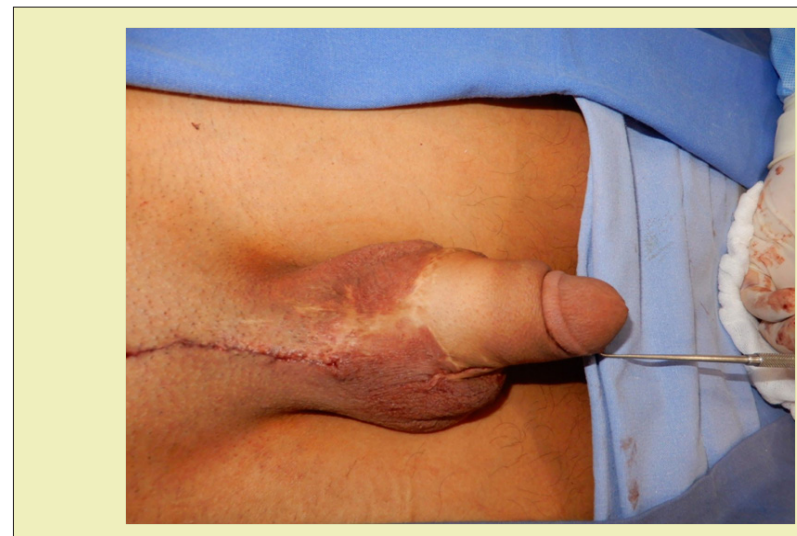

Figure 7: Reconstructed penis after defatting revision (microcannula liposuction).
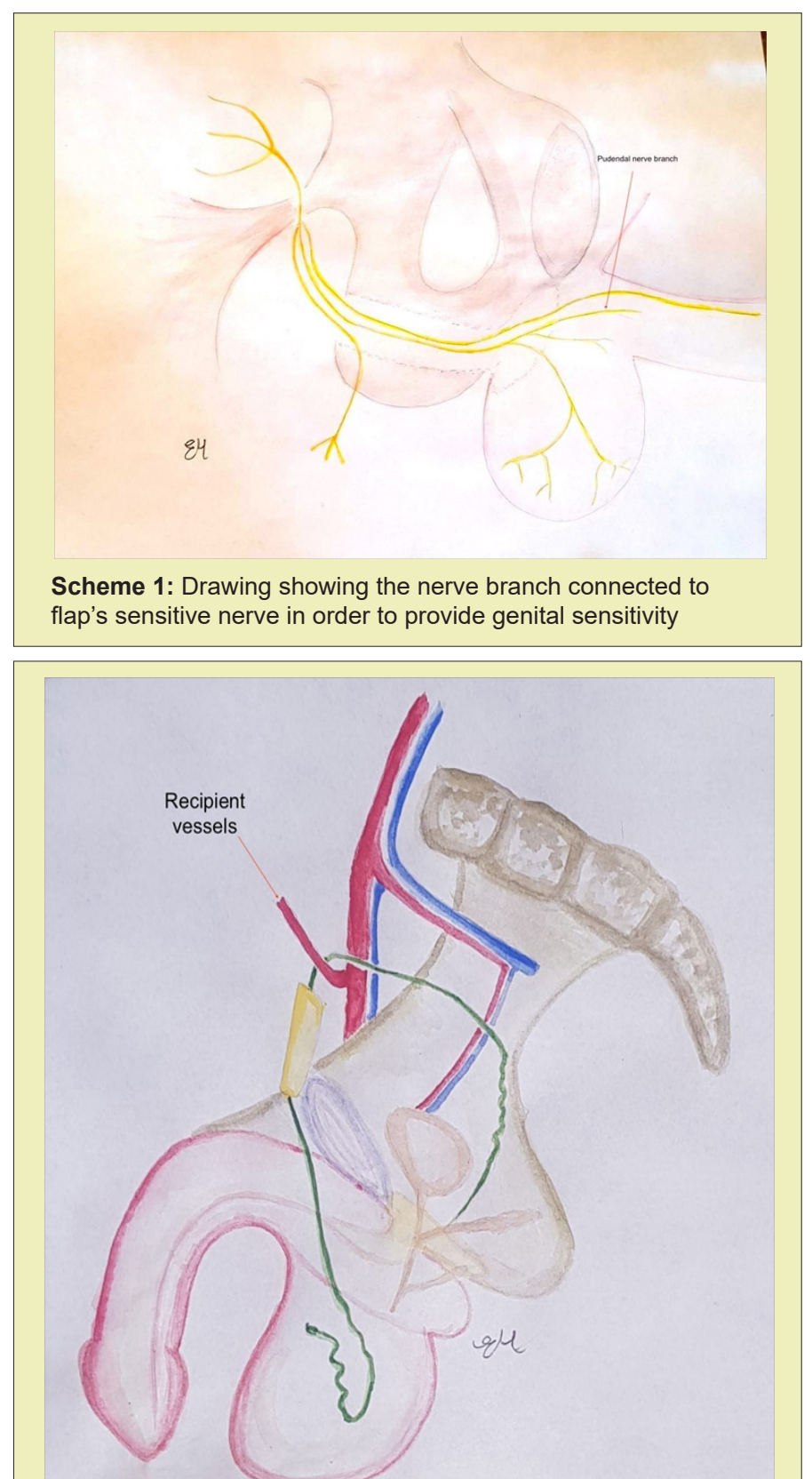

Scheme 2: Recipient vessels from the right deep inferior epigastric artery and veins.

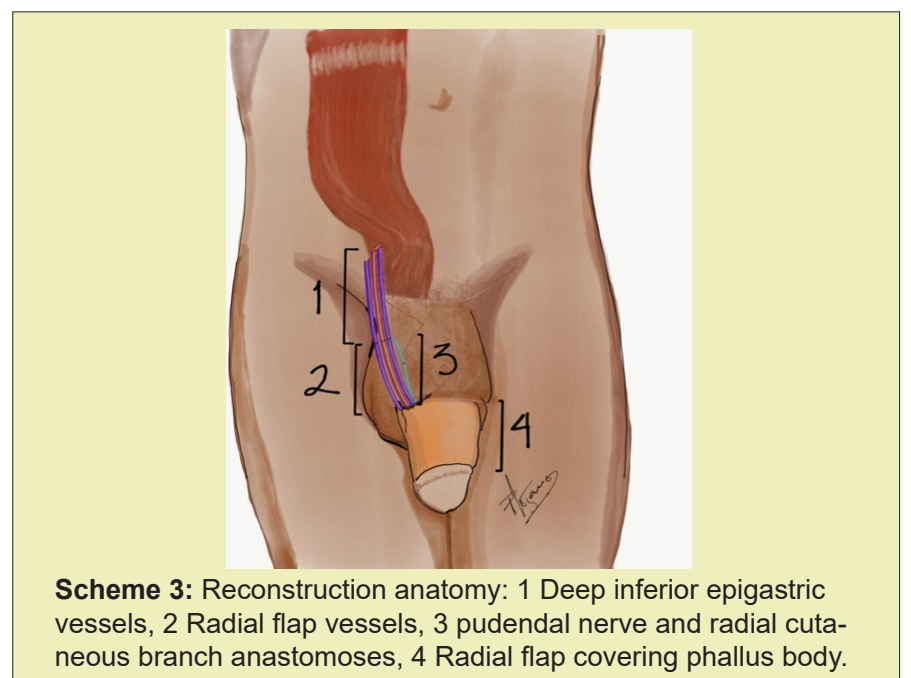

\section{Conclusion}

The majority of reported cases for penile reconstruction are directed to rehabilitate the entire phallus and glans including penile corpus cavernosum and urethra; in cases where only sensitive skin coverage is needed, the forearm flap has shown to be a great tool to meet both coverage and flexibility required for its sexual function and aesthetic appearance.

\section{Acknowledgments}

None.

\section{Funding}

None.

\section{Conflicts of Interest}

Author declares that there is no conflict of interest.

\section{References}

1. Ortiz-Monasterio F, Trigos I. Management of patients with complications from injections of foreign materials into the breasts. Plast Reconstr Surg. 1972;50(1):42-7.

2. Judet J. Protheses en resins acrylic. Mem Acad Chir. 1947;73(27-28):561.

3. McClelland M, Egbert B, Hanko V, et al. Evaluation of artecoll polymethylmethacrylate implant for soft-tissue augmentation: biocompatibility and chemical characterization. Plast Reconstr Surg. 1997;100(6):1466-74.

4. Salles AG, Lotierzo PH, Gemperli R, et al. Complications after polymethylmethacrylate injections: report of 32 cases. Plast Reconstr Surg. 2008;121(5):1811-1820.

5. Priego B, Cárdenas R, Rincón R, et al. Enfermedad humana por modelantes. Análisis de sustancias con espectrometría de resonancia magnética. Cir Plast. 2010;20(3):120-123.

6. Priego B, Rincón R, Serrano A, et al. Clasificación y tratamiento de la enfermedad mamaria por modelantes. Cir Plast. 2010;20(3):112-119.

7. Haddad JL, Nieto A, Saade A, et al. Reconstrucción mamaria con colgajo TRAM bilateral en pacientes mastectomizadas por mastopatía por modelantes. Ann Med (Mex). 2006;51(1):24-28.

8. Dominguez A, Haddad JL, Torres BI, et al. Enfermedad por modelantes: problemática actual en México y presentación de casos. Cir Plast Iberolatinoam. 2013;39(4):400-405.

9. Alegre E, Manzo M, Haddad JL. Enfermedad por modelantes. Presentación poco común en región frontal y en párpados. An Med (Mex). 2013;58(1):2-4. 